\title{
Do Productivity Shocks in the United States Matter to Components of Nigeria's External Sector?
}

\author{
Cukwuemeka 0. Onyimadu ${ }^{*}$, Clifford C. Agbaeze², Daniel U. Sunday² \\ ${ }^{1}$ Department of Economic Development and Social Studies, National Institute for Legislative and Democratic Studies, National \\ Assembly, Abuja, Nigeria \\ ${ }^{2}$ Department of Banking and Finance, Michael Okpara University of Agriculture, Umudike, Nigeria \\ Email: *onyimadu.chukwuemek@nils.gov.ng
}

How to cite this paper: Onyimadu, C.O., Agbaeze, C.C. and Sunday, D.U. (2020) Do Productivity Shocks in the United States Matter to Components of Nigeria's External Sector? Theoretical Economics Letters, 10, 180-197.

https://doi.org/10.4236/tel.2020.101012

Received: January 10, 2020

Accepted: February 22, 2020

Published: February 25, 2020

Copyright $\odot 2020$ by author(s) and Scientific Research Publishing Inc. This work is licensed under the Creative Commons Attribution International License (CC BY 4.0).

http://creativecommons.org/licenses/by/4.0/

\begin{abstract}
The paper examines the effects of United States productivity shock on components of Nigeria's external sector. Using a structural Macroeconomic Model (SMM), the paper modelled Nigeria's external sector by using ten behavioural equations and four identities. The SMM was simulated, using a 3\% increase and $3 \%$ decrease in US productivity to elicit responses of Nigeria's external sector components to this shock. Using quarterly data from 1981 to 2015, the paper found that both positive and negative US productivity shocks elicited symmetrical responses from Nigeria's external sector components. Also, both positive and negative shocks had little effects on Nigeria's current account balance, imports, exports, foreign direct investments and reserves. However, positive shocks increased remittances inflow, a depreciation in nominal exchange rates, a reduction in foreign portfolio investment position, and a reduction in foreign debt flows. The responses for a negative US productivity shock were just the direct opposite of a positive shock. Our finding shows that, the components of Nigeria's external sector will respond in like manner to both positive and negative shocks to United States productivity.
\end{abstract}

\section{Keywords}

Exogenous Shocks, External Sector, Macroeconomic Modelling, Productivity Shocks

\section{Introduction}

Countries engage in a dynamic and complex world of international trade and capital flows; this infers that public policymakers, business planners and other stakeholders in these countries, have to embrace a larger knowledge set that en- 
ables them to become effective economic agents in the global market. With the general expansion of international trade and cooperation, countries and businesses alike, now have an advantageous option of expanding their activities to other countries of the world to achieve their objective: increasing profits, competing for a larger market share, or enhancing their material well-being through trade relations.

One of the government's objectives is to use policy measures to ensure a favourable external balance, whereby the inflow of income (especially from exports) is at least equal to the outflow of income (especially from imports) [1]. Economic literature has documented both favourable economic outcomes for a current account deficit [2] and an unfavourable economic outcome [3]. Also, a current account surplus-when exports are more than imports-may improve domestic employment through improvements in the production of competitive goods and services (in the case of China see [4]) and may also discourage domestic employment if a recession triggers the surplus which then discourages domestic spending and a reduction in import spending (in the case of Japan see [5]).

The disturbances-stochastic economic actions by both domestic and foreign economic agents-that originate from abroad as well as those originating domestically have significant influences and repercussions. These repercussions are transmitted through the components of the external sector to domestic macroeconomic variables [6]. The disturbances that originate from abroad are not controlled by domestic economic policies, unlike disturbances that originate from within the economy. These foreign disturbances are the exogenous shocks. Shocks may be a significant change in the value of a variable from its underlying trend or a sudden event beyond the control of authorities that has a significant impact on the economy [7]. These definitions infer that shocks are simply a deviation from the norm or trend which is unanticipated and has significant effects on the economy, which requires some form of adjustment. This study focuses on the effects of exogenous shocks from abroad on the components of the external sector.

Against this backdrop, investigating the effects of productivity shocks of the United States on Nigeria's external sector components will serve as a useful guide for policy responses to the occurrence of an unfavorable shock. Despite the importance of eliciting external sector responses to exogenous shocks, there is very limited number of studies that has looked into this. From the literature, there exist a handful of studies that has elicited the external sector response to exogenous shocks; [8]-[16].

Given the structure and direction of trade between Nigeria and the United States, to presume only crude oil prices and crude production shocks may not be able to show the necessary reaction dynamics necessary for policy making and forecast. Though crude oil prices and production shocks have considerable feedback effects on both the components of the external sector and the real sector in Nigeria [8] and [13], there has been no documentation of exogenous 
shocks to productivity of Nigeria's major trade partners, despite documentation of its influence on the external sector components in Nigeria [8] and [9]. On this basis, the study sets out to: 1) Expand on the literature on the effects of productivity shocks of trading partners 2) Show the effects of productivity shocks on the Nigerian external sector, and 3) Provide possible policy implications of these shocks. In Section 2, a literature review is provided, while, in Sections 3 and 4, the study provides the methodology used and the findings, respectively. Conclusions are provided in Section 5 .

\section{Literature Review}

With the increasing rates of globalization and international trade among countries, it will be intuitive to conclude that international policies of various governments will have some degree of influence on the macro economy and growth of other countries they engage in trade with. However, there exists substantial controversy on how countries growth rates and international policies interact [17]. The major contentions on the expected relationship between growth rates of countries, boarders on the level of openness, international trade, globalization and governments policies towards protecting domestic infant industries. While studies by [18], support the possibility of positive country growth effects through degree of openness and trade other studies by [19] concluded with negative country growth effects.

[20] studied the impact of the US economic growth on the rest of the world. They used a panel data set with fixed effects and found that there exists a significant positive effect of the US economic growth shock on world economic growth, especially for developing economies. They attributed their findings to the fact that the US is an important global trade partner. They explained their findings through the effects of strong conditional convergence if a country's trading partner is rich. The implication of this is that, developing economies benefit from trading with industrial countries due to their relatively higher incomes. Also, industrial countries benefit from trading with developing economies because of the possibility of their rapid growth.

[21] studied the impact of international trade on economic growth in Nigeria. They concentrated on using external sector components as the transmission mechanism for the effects of international trade. Thus, using balance of payments and net exports in a cointegrating relationship, they found that international trade through exports has a significant positive effect on the Nigerian economy. These findings are supported by [22], where they studied the nexus between foreign trade and economic growth. Using quarterly data in a VAR system, they found foreign trade innovations from other countries serve as a predominant source of growth variations in Nigeria.

[23] expanded on the growth-openness debate on if it is beneficial for industrial countries to enter into trade with developing countries. Some researchers [18], argue that trade with developing countries can be beneficial as it will bring 
about specialization in advanced sectors. However, [23] postulated that this conclusion will only be valid within some specific conditions. These conditions include the existence of learning by doing and homothetic preferences. The study concluded that a rich country could actually become worse off if it trades with a poorer country, when the demand pattern of the poor country tends towards sectors that have a weak learning by doing process.

\section{Methodology}

In this study, the relationships between the components of the external sector and the effects of a US productivity shock on the external sector are examined using a Structural Macroeconomic model (SMM). Structural macroeconomic models are built using economic relationships established from theory. The SMM relies on a system of simultaneous equations in trying to measure the whole economy or a sub-sector of the economy, with each equation specifying a single relationship [24]. The SMM methodology follows, in principle the Cowles Commission approach as used in [25] macroeconomic model. In this approach, economic theory determines the nature of relationship between the right hand side and left hand side variables for all stochastic equations used in building the macro-model. The resulting equations are estimated using a consistent estimation technique [26] [27].

Abstracting form [26] [28] SMM model, the SMM model is specified in its non-linear form as;

$$
f_{i}=\left(y_{t}, y_{t-1}, y_{t-p}, x_{t}, \alpha_{i}\right)=\mu_{i t}, i=1, \cdots, n ; t=1, \cdots, T
$$

where $y$ is an $n$-dimensional vector for all endogenous variables, $x$, is also a vector of all predetermined exogenous variables including lags of endogenous variables, $\alpha$, is a vector of all unknown coefficients and $\mu$, represents the stochastic error term for equations $i$ for period 1 . The firm $m$ equations are assumed to be stochastic and the remaining equations identities. Thus specifying the model will entail choosing the variables that enter into each equation with non-zero elements, the functional form for each equation, and the probability structure of the error term.

The behavioral equations in the SMM model are estimated using ordinary least square (OLS) with the inclusions of lags for both dependent and independent variables in each behavioral equation. According to [27], macroeconomic models are normally nonlinear, simultaneous and very large, thus they tend to have serially correlated error terms. However, the features of the SMM allows for the correction of these problems in modeling the SMM. The SMM provides a convenient way of correcting for the problem of serial correlation by treating the serial correlation coefficients as structural coefficients and transforms the equa-

${ }^{1}$ Assume $\mu_{i t}=\rho_{i} \mu_{i t-1}+\epsilon_{i t} \quad(t=2, \cdots, T)$ where $\epsilon_{i t}$ does not have serial correlated properties. Taking lags of this equation and subtracting it from the original equation 3.2 , we get $f\left(y_{i}, x_{i}, \alpha_{i}\right)-\rho f\left(y_{i-1}, x_{i-1}, \alpha_{i}\right)=\mu_{i t}-\rho_{i} \mu_{i t-1}=\epsilon_{i t}$. This transformation removes the problem of serial correlation when using OLS to estimate the behavioural equations in a SMM. 
tions into equations with serially uncorrelated error terms [27] ${ }^{1}$.

Thus, the SMM used in estimating the effects of exogenous shocks on Nigeria's external sector components comprises the following behavioral equations, modelled as:

$$
\begin{aligned}
& X_{0}=V_{0,1}+V_{1,1} P_{0(t-2)}+V_{2,1} O P E C_{(t-2)}+V_{3,1} Y_{(t-1)}^{f}+V_{4,1} X_{0(t-3)}+\mu_{1} \\
& X_{n}=V_{0,2}+V_{1,2} R E R+V_{2,2} Y_{(t-2)}^{f}+V_{3,2} Y_{n(t-2)}+V_{4,2} X_{n(t-3)}+\mu_{2} \\
& X_{s}=V_{0,3}+V_{1,3} Y+V_{2,3} X_{(t-2)}+V_{3,3} R E R+V_{4,3} X_{s(t-3)}+\mu_{3} \\
& M=V_{0,4}+V_{1,4} Y_{(t-2)}^{d}+V_{2,4} R E R+V_{3,4} M L R_{(t-1)}+V_{4,4} R E S_{(t-3)}+V_{5,4} M_{(t-2)}+\mu_{4} \\
& R E S=V_{0,5}+V_{1,5} R E R+V_{2,5} P_{0}+V_{3,5} E D S_{t-1}+V_{4,5} M_{(t-2)} \\
& +V_{5,5} R E S_{(t-3)}+V_{6,5} Y_{(t-2)}+\mu_{5} \\
& N E R=V_{0,6}+V_{1,6} R E S+V_{2,6} R M T_{(t-1)}+V_{3,6} I R D_{(t-1)}+V_{4,6} X / M \\
& +V_{5,6} C P I_{(t-1)}+V_{6,6} T G E_{(t-1)}+V_{7,6} P_{0(t-2)}+V_{8,6} N E R_{(t-3)}+\mu_{6} \\
& F D I=V_{0,7}+V_{1,7} P C G D P_{(t-2)}+V_{2,7} X_{n(t-4)}+V_{3,7} F D I_{(t-2)}+\mu_{7} \\
& F P I=V_{0,8}+V_{1,8} Y_{(t-1)}+V_{2,8} Y_{(t-2)}^{f}+V_{3,8} S M R+V_{4,8} I N T_{(t-2)}^{f} \\
& +V_{5,8} N E R_{(t-2)}+V_{6,8} F P I_{(t-3)}+\mu_{8} \\
& F D F=V_{0,9}+V_{1,9} I R D_{(t-1)}+V_{2,9} N E R_{(t-2)}+V_{3,9} C R_{(t-2)}+V_{4,9} M_{(t-4)} \\
& +V_{5,9} Y_{(t-2)}^{f}+V_{6,9} F D F_{(t-4)}+\mu_{9} \\
& R M T=V_{0,10}+V_{1,10} N E R+V_{2,10} Y^{u s}+V_{3,10} R M T_{(t-3)}+\mu_{10}
\end{aligned}
$$

Identities

$$
\begin{gathered}
R E R=N E R *(F C P I / C P I) \\
X=X_{0}+X_{n} \\
C A=X-M-I N V I-X_{s}+C T \\
C F=F D I+F P I+O I
\end{gathered}
$$

where $X_{0}$ is oil exports, $P_{0}$ is oil prices, OPEC represents OPEC quota and $Y^{F}$ is the income or foreign output proxy by OECD, $X_{n}$ is non-oil exports, $N E R$ is the nominal exchange rates, $Y_{n}$ is non-oil GDP, $X_{s}$ is service exports, $Y$ is domestic income, $X$ is the value of exports, and $R E R$ is the real exchange rate, $M$ is imports, $Y^{d}$ represents personal disposable income, $R E R$ is real exchange rate, $M L R$ is domestic lending rate, RES is external reserves, EDS is external debt services, $F D I$ represents foreign direct investment, $F D I_{i-1}$ is the previous value of foreign direct investment, $P C G D P$ is per capita income, $R E S$ is foreign reserves, $R M T$ is remittances, $P_{0}$ is oil prices, $I R D$ is the interest rate differential, $X / M$ is the terms of trade, $C P I$ is the consumer price index, $F C P I$ is foreign country $C P I$ (we used the $C P I$ of the United States given that the nominal exchange rate is expressed in dollar terms), $T G E$ is total government expenditure comprising both recurrent and capital expenditure, FPI represents foreign portfolio investment, $Y$ is domestic GDP, $S M R$ is stock market returns proxy by the returns on the All Share 
Index (ASI), $I N T T^{f}$ is interest rate for OECD countries, $N \dot{E} R$ represents changes in nominal exchange rates, $F D F$ represents foreign debt flow, $C R$ represents the credit risk of the borrowing country proxy by the ratio of gross debt to GDP, $R M T$ represents remittances, $Y^{u s}$ represents income from the United States of America, $I N V I$ represents investment income, $C A$ is the current account balance, $C F$ is capital financial flows, $O I$ represents other investments in the capital account and $C T$ represents the net current transfers as captured in the current account balance.

\subsection{Simulation Results for Within-Sample SMM}

Using the estimated behavioural equations, we introduce all the variables-endogenous and exogenous - and identities into the SMM and solve the SMM block using the Gauss-Seidel method. The first step in using the Gauss-Seidel method to study the effects of US productivity shocks on the external sector components is to compare actual and simulated values for all the endogenous variables. This comparison will provide an assessment of the SMM against the historical data on all endogenous variables. The simulated results perform quite well in predicting the general trend for the endogenous variables, making them appropriate for simulating the SMM (see Figure 1).

With satisfactory within-sample simulations for the SMM, we provide out-of-sample simulations for the external sector components, assuming specific shocks to US productivity. With this assumption, the SMM will be able to track responses to this shock in all the external sector components. First, we have to provide a baseline forecast of the external sector components, which will then form the yardstick for comparing simulated responses to shocks of the external sector components. Also, we introduce different scenarios to capture our assumptions of changes to the exogenous shock variables, while also assuming that the conditions within the baseline will hold true in the future.

\subsection{Simulation Results for Out-of-Sample SMM}

The study presents the SMM simulations for foreign country productivity positive shocks and then the results for foreign country productivity negative shocks. In simulating the effects of foreign country productivity shock, the study first assumed that foreign country productivity increases by $3 \%$ for positive shocks and simulate the responses of the external sector components. The study also assumed that foreign productivity reduces by $3 \%$ for negative shocks and simulated the responses of external sector components. For both simulations, all the other exogenous variables will continue on their trend path and not deviate from it within the period of simulation.

A closer look at the simulation results and the percentage deviations show with an increase in foreign country productivity by $3 \%$, the following responses of external sector components were elicited (see Table 1) with the percent deviation from the benchmark represented in Figure 2: 
CA

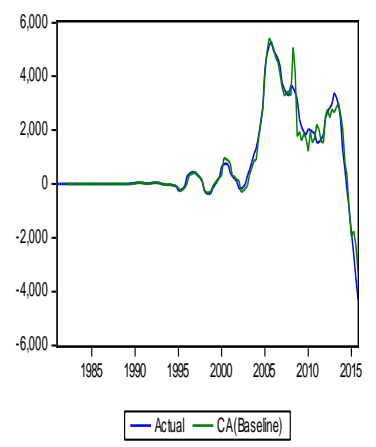

FPI

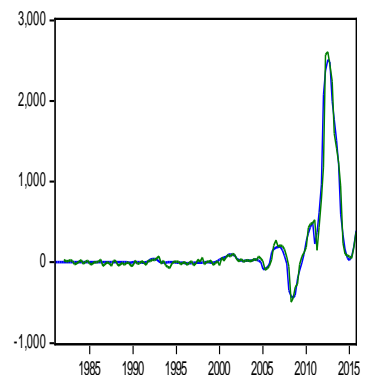

- Actual - FP((Baseline)

RES

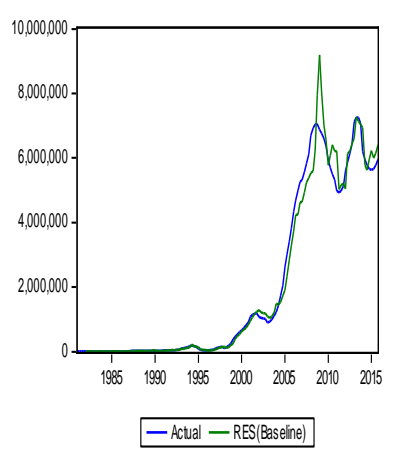

XN

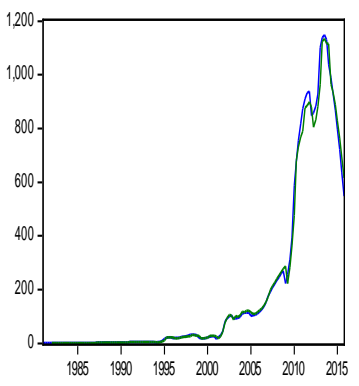

- Actual -XN(Baseline)
CF
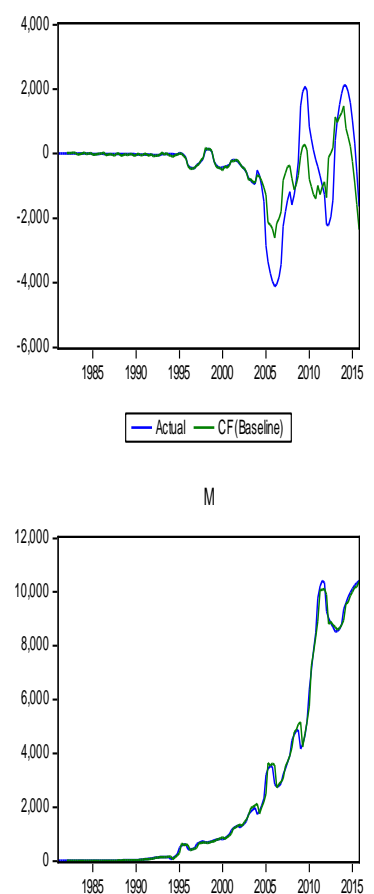

-Actual -M(Baseline)

RMT
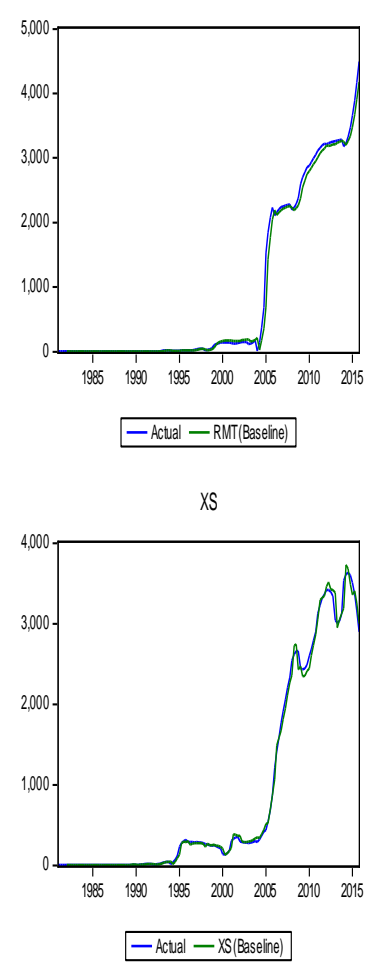

FDF

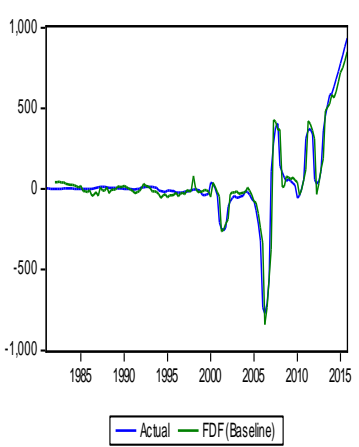

NER

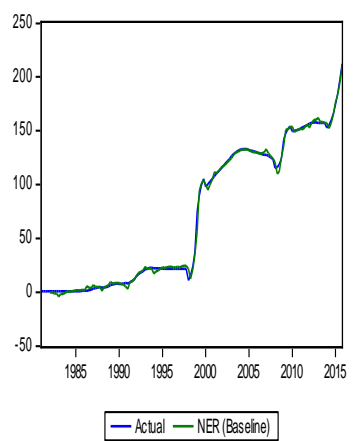

X

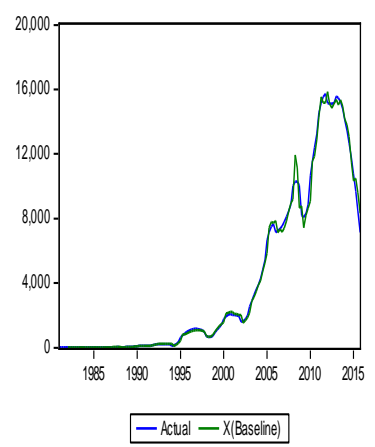

FDI

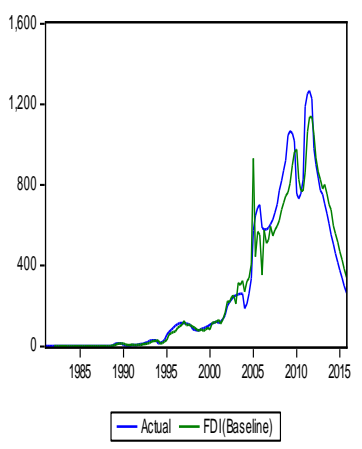

RER

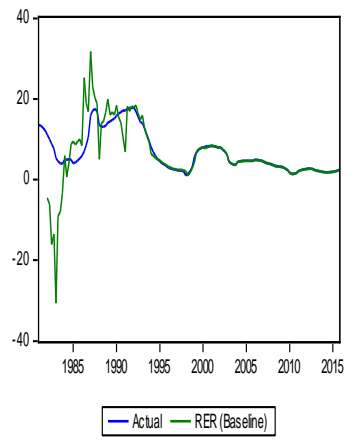

XO

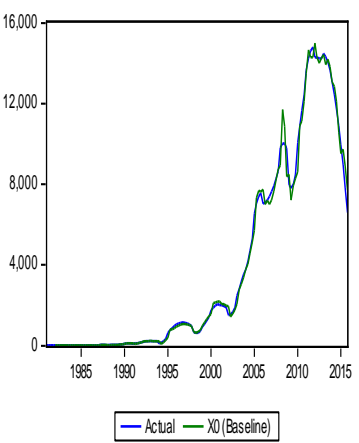

Figure 1. Actual and simulated values for all the external sector components. The simulated results are a close fit to the actual data. This makes the simulated results appropriate for within and out-of-sample simulations. $C A$ is the current account balance, $C F$ is capital financial flows, $F D F$ is the foreign debt flow, $F D I$ is foreign direct investments, $F P I$ is foreign portfolio investments, $M$ is imports, $N E R$ is nominal exchange rate, $R E R$ is real exchange rate, RES is the reserves, $R M T$ is remittances, $X$ is exports, $X_{0}$ is oil exports, $X_{n}$ is non-oil exports, and $X_{s}$ is services exports. 
C. O. Onyimadu et al.

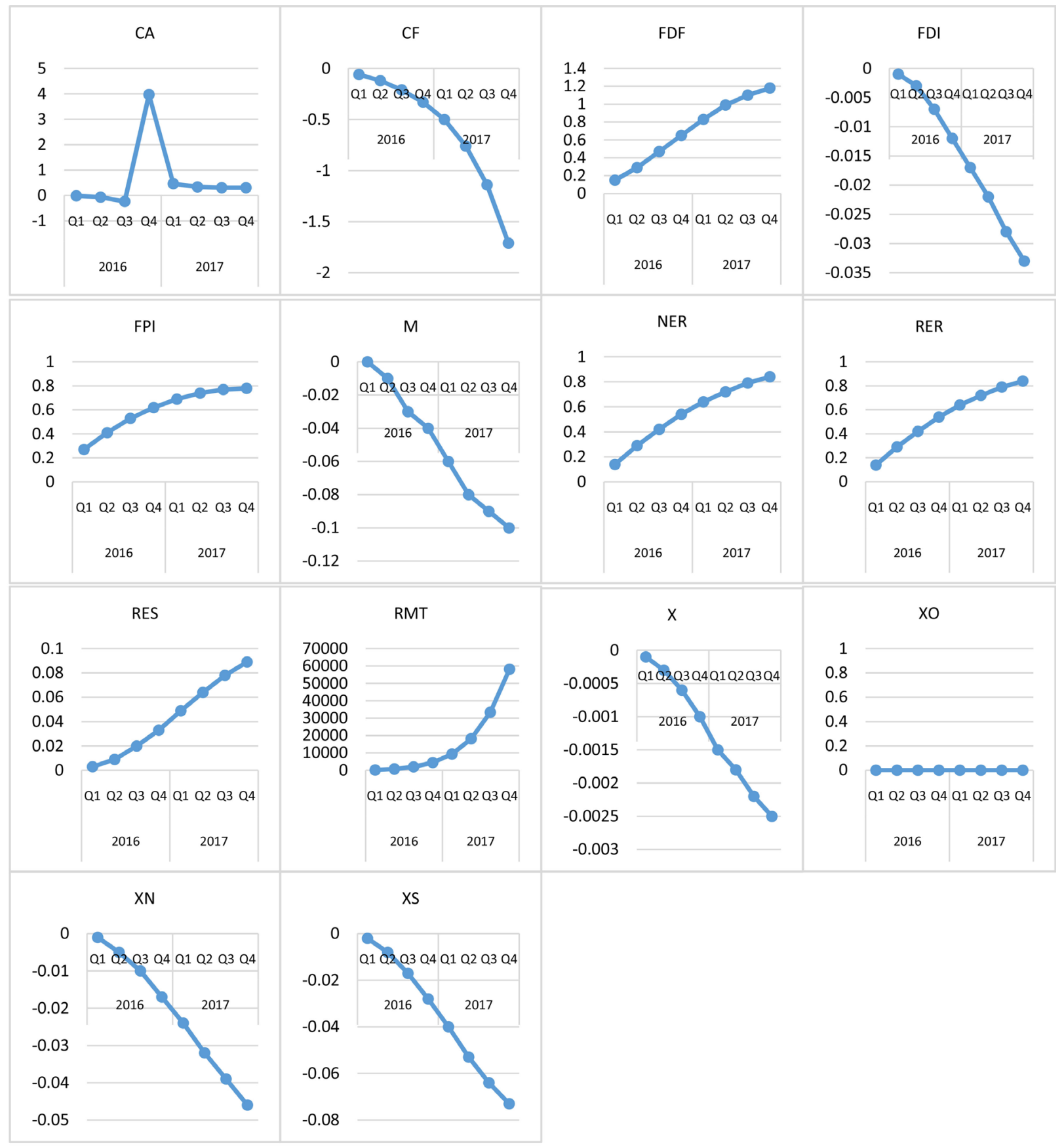

Figure 2. Percent deviations of external sector components to a positive productivity shock. Note: Deviations from the zero line indicates the percent change in response to the productivity shock. All $y$-axis measures percent deviations and $x$-axis capture forward-looking quarters (8 periods). $C A$ is the current account balance, $C F$ is capital financial flows, $F D F$ is the foreign debt flow, $F D I$ is foreign direct investments, $F P I$ is foreign portfolio investments, $M$ is imports, $N E R$ nominal exchange rate, $R E R$ is real exchange rate, $R E S$ is the reserves, $R M T$ is remittances, $X$ is exports, $X_{0}$ is oil exports, $X_{n}$ is non-oil exports, and $X_{s}$ is services exports. Source: Author's computation.

1) Current account balance continuously increases during the forecast period by $0.01 \%$ and above $0.31 \%$ in $2016 \mathrm{Q} 1$ and $2017 \mathrm{Q} 4$ respectively.

2) Capital financial flows increase by $0.06 \%$ to $1.17 \%$ in $2016 \mathrm{Q} 1$ and $2017 \mathrm{Q} 4$ respectively. 
Table 1. Response of external sector components to a positive foreign country productivity cost.

\begin{tabular}{|c|c|c|c|c|c|c|c|c|c|}
\hline \multicolumn{6}{|c|}{2016} & \multicolumn{4}{|c|}{2017} \\
\hline & Q1 & Q2 & Q3 & Q4 & & Q1 & Q2 & Q3 & Q4 \\
\hline \multicolumn{10}{|c|}{$C A$} \\
\hline Scenario 2 ( billion) & -3727.40 & -2640.30 & -1294.40 & 128.7 & Scenario 2 ( billion) & 1492.20 & 2695.70 & 3670.50 & 4383.20 \\
\hline Scenario 1 ( billion) & -3727.90 & -2641.70 & -1297.40 & 123.8 & Scenario 1 ( billion) & 1485.20 & 2686.40 & 3659.10 & 4369.80 \\
\hline Deviation ( billion) & 0.4 & 1.5 & 3 & 4.9 & Deviation ( billion) & 7 & 9.3 & 11.4 & 13.4 \\
\hline \% Deviation & -0.01 & -0.06 & -0.23 & 3.97 & \% Deviation & 0.47 & 0.34 & 0.31 & 0.31 \\
\hline \multicolumn{10}{|c|}{$C F$} \\
\hline Scenario 2 ( billion) & -2731.10 & -2732.60 & -2502.30 & -2136.50 & Scenario 2 ( billion) & -1711.80 & -1291.90 & -921.1 & -625.8 \\
\hline Scenario 1 ( billion) & -2732.70 & -2735.80 & -2507.50 & -2143.60 & Scenario 1 ( billion) & -1720.40 & -1301.70 & -931.7 & -636.7 \\
\hline Deviation ( billion) & 1.6 & 3.3 & 5.2 & 7.1 & Deviation ( billion) & 8.6 & 9.9 & 10.6 & 10.9 \\
\hline \% Deviation & -0.06 & -0.12 & -0.21 & -0.33 & \% Deviation & -0.5 & -0.76 & -1.14 & -1.71 \\
\hline \multicolumn{10}{|c|}{$F D F$} \\
\hline Scenario 2 ( billion) & 910.2 & 858.8 & 801.3 & 758.6 & Scenario 2 ( billion) & 738.9 & 744.4 & 772.4 & 818.5 \\
\hline Scenario 1 ( billion) & 908.9 & 856.3 & 797.6 & 753.6 & Scenario 1 ( billion) & 732.8 & 737.1 & 764 & 808.9 \\
\hline Deviation ( billion) & 1.33 & 2.46 & 3.72 & 4.91 & Deviation ( billion) & 6.1 & 7.26 & 8.42 & 9.55 \\
\hline \% Deviation & 0.15 & 0.29 & 0.47 & 0.65 & \% Deviation & 0.83 & 0.99 & 1.1 & 1.18 \\
\hline \multicolumn{10}{|c|}{$F D I$} \\
\hline Scenario 2 ( billion) & 299.1 & 323.3 & 350.4 & 374.2 & Scenario 2 (billion) & 398.5 & 422.8 & 447.4 & 472.3 \\
\hline Scenario 1 ( billion) & 299.1 & 323.4 & 350.4 & 374.3 & Scenario 1 (billion) & 398.6 & 422.9 & 447.6 & 472.4 \\
\hline Deviation ( billion) & 0 & -0.01 & -0.02 & -0.04 & Deviation ( billion) & -0.07 & -0.09 & -0.12 & -0.16 \\
\hline \% Deviation & -0.001 & -0.003 & -0.007 & -0.012 & \% Deviation & -0.017 & -0.022 & -0.028 & -0.033 \\
\hline \multicolumn{10}{|c|}{$F P I$} \\
\hline Scenario 2 ( billion) & 591.3 & 796.7 & 984.2 & 1142.90 & Scenario 2 ( billion) & 1266.00 & 1351.50 & 1401.00 & 1418.80 \\
\hline Scenario 1 ( billion) & 589.7 & 793.4 & 979 & 1135.80 & Scenario 1 (billion) & 1257.30 & 1341.50 & 1390.20 & 1407.70 \\
\hline Deviation ( billion) & 1.6 & 3.3 & 5.2 & 7.1 & Deviation ( billion) & 8.7 & 9.9 & 10.7 & 11 \\
\hline \% Deviation & 0.27 & 0.41 & 0.53 & 0.62 & \% Deviation & 0.69 & 0.74 & 0.77 & 0.78 \\
\hline \multicolumn{10}{|c|}{$M$} \\
\hline Scenario 2 ( billion) & $10,363.10$ & $10,304.70$ & $10,302.40$ & $10,381.80$ & Scenario 2 ( billion) & $10,550.60$ & $10,803.90$ & $11,132.20$ & $11,524.50$ \\
\hline Scenario 1 ( billion) & $10,363.50$ & $10,306.00$ & $10,305.00$ & $10,386.10$ & Scenario 1 ( billion) & $10,556.80$ & $10,812.00$ & $11,142.20$ & $11,536.10$ \\
\hline Deviation ( billion) & -0.4 & -1.3 & -2.6 & -4.3 & Deviation ( billion) & -6.2 & -8.1 & -10 & -11.6 \\
\hline \% Deviation & 0 & -0.01 & -0.03 & -0.04 & \% Deviation & -0.06 & -0.08 & -0.09 & -0.1 \\
\hline \multicolumn{10}{|c|}{$N E R$} \\
\hline Scenario $2(\mathbb{N})$ & 227.9 & 243.1 & 258.4 & 273.6 & Scenario $2(\mathbb{N})$ & 288.7 & 303.6 & 318.5 & 333.2 \\
\hline Scenario $1(\mathbb{N})$ & 227.5 & 242.5 & 257.4 & 272.1 & Scenario $1(\mathrm{~N})$ & 286.8 & 301.5 & 316 & 330.4 \\
\hline Deviation & 0.32 & 0.69 & 1.09 & 1.47 & Deviation & 1.84 & 2.18 & 2.49 & 2.76 \\
\hline \% Deviation & 0.14 & 0.29 & 0.42 & 0.54 & \% Deviation & 0.64 & 0.72 & 0.79 & 0.84 \\
\hline
\end{tabular}




\section{Continued}

\begin{tabular}{|c|c|c|c|c|c|c|c|c|c|}
\hline \multicolumn{10}{|c|}{$R E R$} \\
\hline Scenario $2(\sharp)$ & 2.6 & 2.7 & 2.7 & 2.6 & Scenario $2(\sharp)$ & 2.6 & 2.4 & 2.3 & 2.1 \\
\hline Scenario $1(\#)$ & 2.6 & 2.7 & 2.7 & 2.6 & Scenario $1(\mathbb{N})$ & 2.5 & 2.4 & 2.3 & 2.1 \\
\hline Deviation & 0.004 & 0.008 & 0.011 & 0.014 & Deviation & 0.016 & 0.018 & 0.018 & 0.018 \\
\hline \% Deviation & 0.14 & 0.29 & 0.42 & 0.54 & $\%$ Deviation & 0.64 & 0.72 & 0.79 & 0.84 \\
\hline \multicolumn{10}{|c|}{$R E S$} \\
\hline Scenario 2 ( billion) & $6.45 \mathrm{E}+06$ & $6.91 \mathrm{E}+06$ & $7.39 \mathrm{E}+06$ & $7.83 \mathrm{E}+06$ & Scenario 2 ( billion) & $8.22 \mathrm{E}+06$ & $8.56 \mathrm{E}+06$ & $8.84 \mathrm{E}+06$ & $9.07 \mathrm{E}+06$ \\
\hline Scenario 1 ( billion) & $6.45 \mathrm{E}+06$ & $6.90 \mathrm{E}+06$ & $7.39 \mathrm{E}+06$ & $7.82 \mathrm{E}+06$ & Scenario 1 ( billion) & $8.22 \mathrm{E}+06$ & $8.55 \mathrm{E}+06$ & $8.83 \mathrm{E}+06$ & $9.06 \mathrm{E}+06$ \\
\hline Deviation ( billion) & 170 & 632 & 1454.00 & 2606.00 & Deviation ( billion) & 3989.00 & 5462.00 & 6874.00 & 8095.00 \\
\hline \% Deviation & 0.003 & 0.009 & 0.02 & 0.033 & $\%$ Deviation & 0.049 & 0.064 & 0.078 & 0.089 \\
\hline \multicolumn{10}{|c|}{$R M T$} \\
\hline Scenario 2 ( billion) & 4411 & 4338 & 4257 & 4154 & Scenario 2 (billion) & 4035 & 3904 & 3764 & 3618 \\
\hline Scenario 1 ( billion) & 1318 & 484.07 & 203.16 & 90.223 & Scenario 1 ( billion) & 42.601 & 21.318 & 11.238 & 6.2114 \\
\hline Deviation ( billion) & 3092.90 & 3853.90 & 4054.20 & 4064.00 & Deviation ( billion) & 3992.40 & 3882.60 & 3752.70 & 3611.70 \\
\hline \% Deviation & 234.6648 & 796.1395 & 1995.61 & 4504.41 & \% Deviation & 9371.52 & $18,212.50$ & $33,392.30$ & $58,146.00$ \\
\hline \multicolumn{10}{|c|}{$X$} \\
\hline Scenario 2 (billion) & 7411.07 & 8202.25 & 9401.30 & $10,835.60$ & Scenario 2 ( billion) & $12,381.10$ & $13,926.70$ & $15,388.60$ & $16,713.40$ \\
\hline Scenario 1 (billion) & 7411.08 & 8202.28 & 9401.36 & $10,835.70$ & Scenario 1 ( billion) & $12,381.30$ & $13,927.00$ & $15,389.00$ & $16,713.90$ \\
\hline Deviation ( billion) & -0.01 & -0.03 & -0.06 & -0.11 & Deviation (billion) & -0.18 & -0.25 & -0.34 & -0.42 \\
\hline \% Deviation & -0.0001 & -0.0003 & -0.0006 & -0.001 & $\%$ Deviation & -0.0015 & -0.0018 & -0.0022 & -0.0025 \\
\hline \multicolumn{10}{|c|}{$X_{0}$} \\
\hline Scenario 2 ( billion) & 6868.07 & 7637.47 & 8792.11 & $10,168.40$ & Scenario 2 ( billion) & $11,648.10$ & $13,125.10$ & $14,519.50$ & $15,780.90$ \\
\hline Scenario 1 ( billion) & 6868.07 & 7637.47 & 8792.11 & $10,168.40$ & Scenario 1 (billion) & $11,648.10$ & $13,125.10$ & $14,519.50$ & $15,780.90$ \\
\hline Deviation ( billion) & 0 & 0 & 0 & 0 & Deviation ( billion) & 0 & 0 & 0 & 0 \\
\hline \% Deviation & 0 & 0 & 0 & 0 & \% Deviation & 0 & 0 & 0 & 0 \\
\hline \multicolumn{10}{|c|}{$X_{n}$} \\
\hline Scenario 2 ( billion) & 543 & 564.8 & 609.2 & 667.1 & Scenario 2 (billion) & 733 & 801.6 & 869.1 & 932.6 \\
\hline Scenario 1 ( billion) & 543 & 564.8 & 609.2 & 667.2 & Scenario 1 ( billion) & 733.1 & 801.9 & 869.5 & 933 \\
\hline Deviation ( billion) & -0.01 & -0.03 & -0.06 & -0.11 & Deviation ( billion) & -0.18 & -0.26 & -0.34 & -0.42 \\
\hline$\%$ Deviation & -0.001 & -0.005 & -0.01 & -0.017 & \% Deviation & -0.024 & -0.032 & -0.039 & -0.046 \\
\hline \multicolumn{10}{|c|}{$X_{S}$} \\
\hline Scenario 2 ( billion) & 2796.80 & 2663.70 & 2582.70 & 2551.00 & Scenario 2 ( billion) & 2582.80 & 2678.90 & 2837.30 & 3052.20 \\
\hline Scenario 1 ( billion) & 2796.90 & 2663.90 & 2583.10 & 2551.70 & Scenario 1 ( billion) & 2583.80 & 2680.30 & 2839.10 & 3054.40 \\
\hline Deviation ( billion) & -0.07 & -0.21 & -0.43 & -0.71 & Deviation ( billion) & -1.04 & -1.41 & -1.81 & -2.22 \\
\hline \% Deviation & -0.002 & -0.008 & -0.017 & -0.028 & $\%$ Deviation & -0.04 & -0.053 & -0.064 & -0.073 \\
\hline
\end{tabular}

Source: Author's computation. Scenario 2 represents responses of external sector components to an increase in foreign country productivity, while Scenario 1 represents the benchmark forecast. Underneath each variable's response is the deviation and percentage deviation of the responses.

3) Foreign debt flow increases by $0.15 \%$ to $1.18 \%$ in $2016 \mathrm{Q} 1$ and $2017 \mathrm{Q} 4$ respectively. 
4) Foreign direct investment decreases by $0.001 \%$ to $0.033 \%$ in $2016 \mathrm{Q} 1$ and 2017Q4 respectively.

5) Foreign portfolio investments increase by $0.27 \%$ to $0.78 \%$ in $2016 \mathrm{Q} 1$ and 2017Q4 respectively.

6) Imports decrease by $0.01 \%$ to $0.1 \%$ in $2016 \mathrm{Q} 1$ and $2017 \mathrm{Q} 4$ respectively.

7) Nominal exchange rates depreciate from $\$ 1$ : N227 to $\$ 1$ : N227.9 by 2016Q1 and from $\$ 1$ : N330.4 to $\$ 1$ : N333.2 by 2017Q4.

8) Real exchange rates also depreciate by $0.14 \%$ to $0.84 \%$ in $2016 \mathrm{Q} 1$ and 2017Q4 respectively.

9) Reserves increase by $0.003 \%$ to $0.089 \%$ in $2016 \mathrm{Q} 1$ and $2017 \mathrm{Q} 4$ respectively.

10) Remittances increase by $\mathrm{N} 3.092$ billion to N3.611 billion in 2016Q1 and 2017Q4 respectively.

11) Total exports decrease by $0.0001 \%$ to $0.0025 \%$ in $2016 \mathrm{Q} 1$ and $2017 \mathrm{Q} 4$ respectively. Oil exports did not respond to a positive foreign country productivity shock and remained unchanged over the period of simulations, while service exports also decreased by $0.002 \%$ to $0.073 \%$ in 2016 Q1 and 2017 Q 4 respectively. However, non-oil exports decrease by $0.001 \%$ to $0.046 \%$ in 2016 Q1 and 2017Q4 respectively.

In simulating the effects of a negative foreign country productivity shock, the study first assumed that foreign country productivity decreases by $3 \%$ and simulate the responses of the external sector components. All the other exogenous variables will continue on their trend path and not deviate from it within the period of simulation.

A closer look at the simulation results from the negative shocks and the percentage deviations show with a decrease in foreign country productivity by $3 \%$, the following responses of external sector components were elicited (see Table 2) with the percent deviation from the benchmark represented in Figure 3:

1) Current account balance continuously increases during the forecast period by $0.01 \%$ and above $0.29 \%$ in 2016Q1 and 2017Q4 respectively.

2) Capital financial flows increase by $0.06 \%$ to $1.6 \%$ in $2016 \mathrm{Q} 1$ and $2017 \mathrm{Q} 4$ respectively.

3) Foreign debt flow increases by $0.14 \%$ to $1.11 \%$ in $2016 \mathrm{Q} 1$ and $2017 \mathrm{Q} 4$ respectively.

4 Foreign direct investment decreases by $0.001 \%$ to $0.032 \%$ in $2016 \mathrm{Q} 1$ and 2017Q4 respectively.

5) Foreign portfolio investments increase by $0.26 \%$ to $0.73 \%$ in $2016 \mathrm{Q} 1$ and 2017Q4 respectively.

6) Imports decrease by $0.004 \%$ to $0.096 \%$ in $2016 \mathrm{Q} 1$ and $2017 \mathrm{Q} 4$ respectively.

7) Nominal exchange rates depreciate from $\$ 1$ : N227 to $\$ 1$ : N227.9 by 2016Q1 and from $\$ 1$ : N330.4 to $\$ 1$ : N333 by 2017Q4.

8) Real exchange rates also depreciate by $0.14 \%$ to $0.79 \%$ in $2016 \mathrm{Q} 1$ and 2017Q4 respectively. 
Table 2. Response of external sector components to a negative foreign country productivity.

\begin{tabular}{|c|c|c|c|c|c|c|c|c|c|}
\hline \multicolumn{6}{|c|}{2016} & \multicolumn{4}{|c|}{2017} \\
\hline & Q1 & Q2 & Q3 & Q4 & & Q1 & Q2 & Q3 & Q4 \\
\hline \multicolumn{10}{|c|}{$C A$} \\
\hline Scenario 3 (billion) & -3727.40 & -2640.30 & -1294.40 & 128.6 & Scenario 3 (billion) & 1492.00 & 2695.30 & 3670.10 & 4382.60 \\
\hline Scenario 1 (billion) & -3727.90 & -2641.70 & -1297.40 & 123.8 & Scenario 1 (billion) & 1485.20 & 2686.40 & 3659.10 & 4369.80 \\
\hline Deviation ( billion) & 0.4 & 1.4 & 2.9 & 4.8 & Deviation ( billion) & 6.8 & 8.9 & 11 & 12.8 \\
\hline \% Deviation & -0.01 & -0.05 & -0.23 & 3.87 & \% Deviation & 0.46 & 0.33 & 0.3 & 0.29 \\
\hline \multicolumn{10}{|c|}{$C F$} \\
\hline Scenario 3 (billion) & -2731.20 & -2732.60 & -2502.40 & -2136.70 & Scenario 3 ( billion) & -1712.10 & -1292.30 & -921.7 & -626.5 \\
\hline Scenario 1 ( billion) & -2732.70 & -2735.80 & -2507.50 & -2143.60 & Scenario 1 ( billion) & -1720.40 & -1301.70 & -931.7 & -636.7 \\
\hline Deviation ( billion) & 1.5 & 3.2 & 5.1 & 6.8 & Deviation ( billion) & 8.3 & 9.4 & 10 & 10.2 \\
\hline$\%$ Deviation & -0.06 & -0.12 & -0.2 & -0.32 & $\%$ Deviation & -0.48 & -0.72 & -1.07 & -1.6 \\
\hline \multicolumn{10}{|c|}{$F D F$} \\
\hline Scenario 3 ( billion) & 910.2 & 858.7 & 801.2 & 758.4 & Scenario 3 ( billion) & 738.7 & 744 & 771.9 & 817.9 \\
\hline Scenario 1 ( billion) & 908.9 & 856.3 & 797.6 & 753.6 & Scenario 1 ( billion) & 732.8 & 737.1 & 764 & 808.9 \\
\hline Deviation ( billion) & 1.31 & 2.41 & 3.63 & 4.75 & Deviation ( billion) & 5.86 & 6.93 & 7.98 & 8.99 \\
\hline$\%$ Deviation & 0.14 & 0.28 & 0.45 & 0.63 & $\%$ Deviation & 0.8 & 0.94 & 1.04 & 1.11 \\
\hline \multicolumn{10}{|c|}{$F D I$} \\
\hline Scenario 3 ( billion) & 299.1 & 323.3 & 350.4 & 374.2 & Scenario 3 ( billion) & 398.5 & 422.8 & 447.5 & 472.3 \\
\hline Scenario 1 (billion) & 299.1 & 323.4 & 350.4 & 374.3 & Scenario 1 ( billion) & 398.6 & 422.9 & 447.6 & 472.4 \\
\hline Deviation ( billion) & 0 & -0.01 & -0.02 & -0.04 & Deviation ( billion) & -0.07 & -0.09 & -0.12 & -0.15 \\
\hline \% Deviation & -0.001 & -0.003 & -0.007 & -0.011 & $\%$ Deviation & -0.016 & -0.022 & -0.027 & -0.032 \\
\hline \multicolumn{10}{|c|}{$F P I$} \\
\hline Scenario 3 ( billion) & 591.3 & 796.6 & 984.1 & 1142.60 & Scenario 3 ( billion) & 1265.70 & 1351.00 & 1400.40 & 1418.00 \\
\hline Scenario 1 ( billion) & 589.7 & 793.4 & 979 & 1135.80 & Scenario 1 ( billion) & 1257.30 & 1341.50 & 1390.20 & 1407.70 \\
\hline Deviation ( billion) & 1.6 & 3.2 & 5.1 & 6.9 & Deviation ( billion) & 8.4 & 9.5 & 10.1 & 10.3 \\
\hline$\%$ Deviation & 0.26 & 0.4 & 0.52 & 0.61 & $\%$ Deviation & 0.67 & 0.71 & 0.73 & 0.73 \\
\hline \multicolumn{10}{|c|}{$M$} \\
\hline Scenario 3 ( billion) & $10,363.10$ & $10,304.70$ & $10,302.40$ & $10,381.90$ & Scenario 3 ( billion) & $10,550.80$ & $10,804.20$ & $11,132.60$ & $11,525.10$ \\
\hline Scenario 1 ( billion) & $10,363.50$ & $10,306.00$ & $10,305.00$ & $10,386.10$ & Scenario 1 ( billion) & $10,556.80$ & $10,812.00$ & $11,142.20$ & $11,536.10$ \\
\hline Deviation ( billion) & -0.4 & -1.3 & -2.6 & -4.2 & Deviation ( billion) & -6 & -7.8 & -9.6 & -11.1 \\
\hline$\%$ Deviation & -0.004 & -0.012 & -0.025 & -0.04 & $\%$ Deviation & -0.057 & -0.072 & -0.086 & -0.096 \\
\hline \multicolumn{10}{|c|}{$N E R$} \\
\hline Scenario 3 ( & 227.9 & 243.1 & 258.4 & 273.6 & Scenario 3 ( & 288.6 & 303.5 & 318.3 & 333 \\
\hline Scenario $1(\boxplus)$ & 227.5 & 242.5 & 257.4 & 272.1 & Scenario $1(\boxplus)$ & 286.8 & 301.5 & 316 & 330.4 \\
\hline Deviation & 0.32 & 0.68 & 1.06 & 1.43 & Deviation & 1.77 & 2.08 & 2.36 & 2.6 \\
\hline$\%$ Deviation & 0.14 & 0.28 & 0.41 & 0.52 & $\%$ Deviation & 0.62 & 0.69 & 0.75 & 0.79 \\
\hline
\end{tabular}




\section{Continued}

\begin{tabular}{|c|c|c|c|c|c|c|c|c|c|}
\hline \multicolumn{10}{|c|}{$R E R$} \\
\hline Scenario 3 ( & 2.6 & 2.7 & 2.7 & 2.6 & Scenario 3 ( $)$ & 2.6 & 2.4 & 2.3 & 2.1 \\
\hline Scenario $1(\mathrm{~N})$ & 2.6 & 2.7 & 2.7 & 2.6 & Scenario $1(\mathbb{N})$ & 2.5 & 2.4 & 2.3 & 2.1 \\
\hline Deviation & 0.004 & 0.007 & 0.011 & 0.014 & Deviation & 0.016 & 0.017 & 0.017 & 0.017 \\
\hline \% Deviation & 0.14 & 0.28 & 0.41 & 0.52 & $\%$ Deviation & 0.62 & 0.69 & 0.75 & 0.79 \\
\hline \multicolumn{10}{|c|}{$R E S$} \\
\hline Scenario 3 ( billion) & $6.45 \mathrm{E}+06$ & $6.91 \mathrm{E}+06$ & $7.39 \mathrm{E}+06$ & $7.83 \mathrm{E}+06$ & Scenario 3 ( billion) & $8.22 \mathrm{E}+06$ & $8.56 \mathrm{E}+06$ & $8.84 \mathrm{E}+06$ & $9.07 \mathrm{E}+06$ \\
\hline Scenario 1 ( billion) & $6.45 \mathrm{E}+06$ & $6.90 \mathrm{E}+06$ & $7.39 \mathrm{E}+06$ & $7.82 \mathrm{E}+06$ & Scenario 1 ( billion) & $8.22 \mathrm{E}+06$ & $8.55 \mathrm{E}+06$ & $8.83 \mathrm{E}+06$ & $9.06 \mathrm{E}+06$ \\
\hline Deviation ( billion) & 168 & 621 & 1424.00 & 2543.00 & Deviation ( billion) & 3876.00 & 5283.00 & 6617.00 & 7753.00 \\
\hline \% Deviation & 0.003 & 0.009 & 0.019 & 0.033 & $\%$ Deviation & 0.047 & 0.062 & 0.075 & 0.086 \\
\hline \multicolumn{10}{|c|}{ RMT } \\
\hline Scenario 3 ( billion) & 4342 & 4151 & 3917 & 3639 & Scenario 3 ( billion) & 3334 & 3018 & 2702 & 2395 \\
\hline Scenario 1 ( billion) & 1318 & 484.07 & 203.16 & 90.223 & Scenario 1 ( billion) & 42.601 & 21.318 & 11.238 & 6.2114 \\
\hline Deviation ( billion) & 3024.30 & 3667.00 & 3714.10 & 3548.50 & Deviation ( billion) & 3291.40 & 2996.50 & 2690.60 & 2389.00 \\
\hline \% Deviation & 229.4635 & 757.5458 & 1828.21 & 3933.04 & $\%$ Deviation & 7726.00 & $14,056.10$ & $23,941.60$ & $38,461.40$ \\
\hline \multicolumn{10}{|c|}{$X$} \\
\hline Scenario 3 ( billion) & 7411.07 & 8202.25 & 9401.30 & $10,835.60$ & Scenario 3 ( billion) & $12,381.10$ & $13,926.70$ & $15,388.60$ & $16,713.50$ \\
\hline Scenario 1 ( billion) & 7411.08 & 8202.28 & 9401.36 & $10,835.70$ & Scenario 1 ( billion) & $12,381.30$ & $13,927.00$ & $15,389.00$ & $16,713.90$ \\
\hline Deviation ( billion) & -0.01 & -0.03 & -0.06 & -0.11 & Deviation ( billion) & -0.17 & -0.25 & -0.33 & -0.41 \\
\hline \% Deviation & -0.0001 & -0.0003 & -0.0006 & -0.001 & $\%$ Deviation & -0.0014 & -0.0018 & -0.0021 & -0.0025 \\
\hline \multicolumn{10}{|c|}{$X_{0}$} \\
\hline Scenario 3 (billion) & 6868.07 & 7637.47 & 8792.11 & $10,168.40$ & Scenario 3 ( billion) & $11,648.10$ & $13,125.10$ & $14,519.50$ & $15,780.90$ \\
\hline Scenario 1 ( billion) & 6868.07 & 7637.47 & 8792.11 & $10,168.40$ & Scenario 1 ( billion) & $11,648.10$ & $13,125.10$ & $14,519.50$ & $15,780.90$ \\
\hline Deviation ( billion) & 0 & 0 & 0 & 0 & Deviation ( billion) & 0 & 0 & 0 & 0 \\
\hline \% Deviation & 0 & 0 & 0 & 0 & $\%$ Deviation & 0 & 0 & 0 & 0 \\
\hline \multicolumn{10}{|c|}{$X_{n}$} \\
\hline Scenario 3 ( billion) & 543 & 564.8 & 609.2 & 667.1 & Scenario 3 ( billion) & 733 & 801.6 & 869.2 & 932.6 \\
\hline Scenario 1 ( billion) & 543 & 564.8 & 609.2 & 667.2 & Scenario 1 (billion) & 733.1 & 801.9 & 869.5 & 933 \\
\hline Deviation ( billion) & -0.01 & -0.03 & -0.06 & -0.11 & Deviation ( billion) & -0.17 & -0.25 & -0.33 & -0.41 \\
\hline \% Deviation & -0.001 & -0.005 & -0.01 & -0.016 & $\%$ Deviation & -0.024 & -0.031 & -0.038 & -0.044 \\
\hline \multicolumn{10}{|c|}{ XS } \\
\hline Scenario 3 ( billion) & 2796.80 & 2663.70 & 2582.70 & 2551.00 & Scenario 3 ( billion) & 2582.80 & 2678.90 & 2837.30 & 3052.30 \\
\hline Scenario 1 (billion) & 2796.90 & 2663.90 & 2583.10 & 2551.70 & Scenario 1 ( billion) & 2583.80 & 2680.30 & 2839.10 & 3054.40 \\
\hline Deviation ( billion) & -0.07 & -0.21 & -0.43 & -0.7 & Deviation ( billion) & -1.01 & -1.37 & -1.74 & -2.13 \\
\hline \% Deviation & -0.002 & -0.008 & -0.016 & -0.027 & \% Deviation & -0.039 & -0.051 & -0.061 & -0.07 \\
\hline
\end{tabular}

Source: Author's computation. Scenario 3 represents responses of external sector components to a decrease in foreign country productivity, while Scenario 1 represents the benchmark forecast. Underneath each variable's response is the deviation and percentage deviation. 


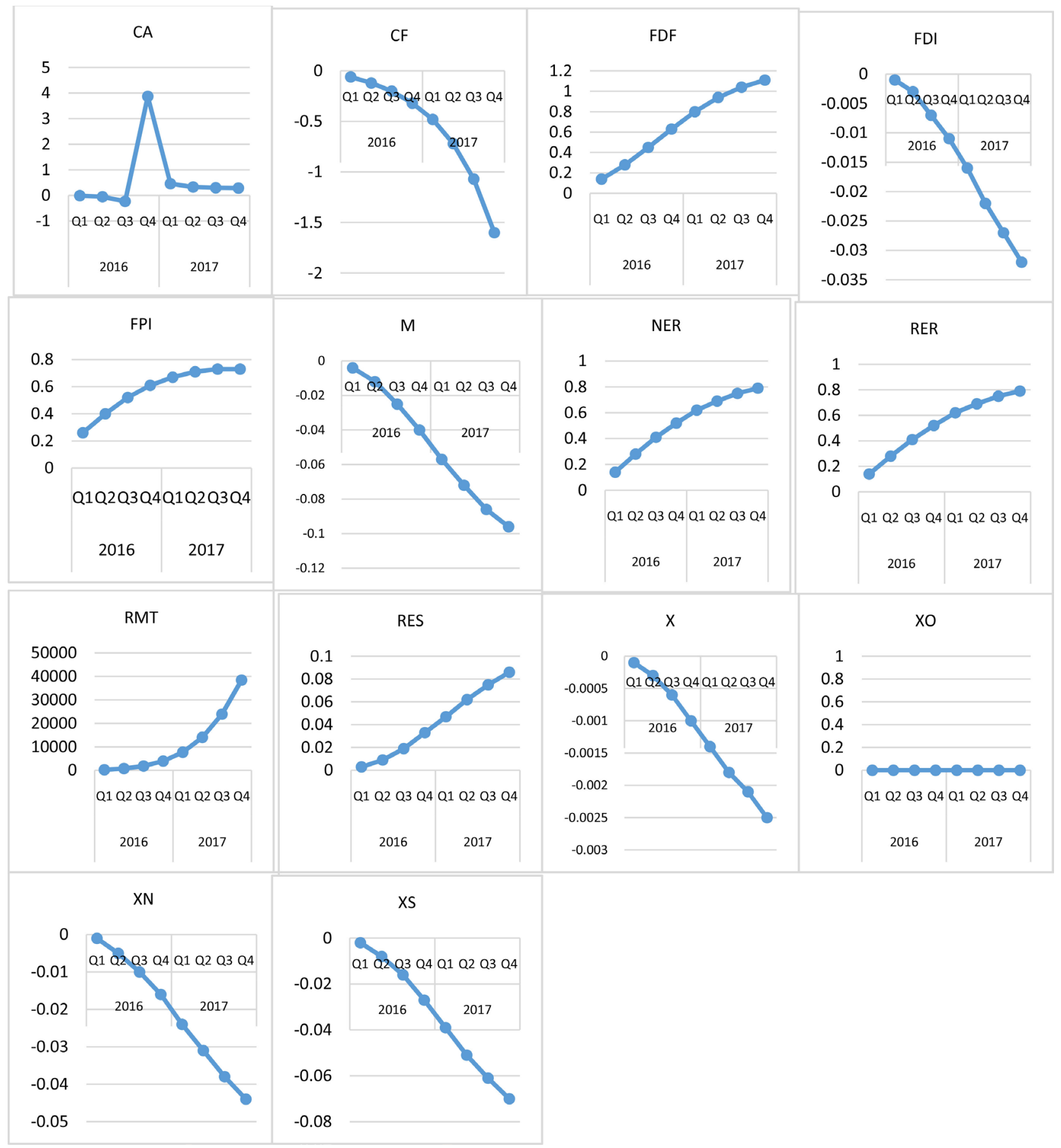

Figure 3. Percent deviations of external sector components to a negative productivity. Note: Deviations from the zero line indicates the percent change in response to the productivity shock. All $y$-axis measures percent deviations and $x$-axis capture forward-looking quarters (8 periods). $C A$ is the current account balance, $C F$ is capital financial flows, $F D F$ is the foreign debt flow, $F D I$ is foreign direct investments, $F P I$ is foreign portfolio investments, $M$ is imports, $N E R$ nominal exchange rate, $R E R$ is real exchange rate, RES is the reserves, $R M T$ is remittances, $X$ is exports, $X_{0}$ is oil exports, $X_{n}$ is non-oil exports, and $X_{s}$ is services exports. Source: Author's computation.

9) Reserves increase by $0.003 \%$ to $0.086 \%$ in $2016 \mathrm{Q} 1$ and $2017 \mathrm{Q} 4$ respectively.

10) Remittances increase initially by N3.024 billion by 2016Q1, but decreases to $\mathrm{N} 2.389$ billion by $2017 \mathrm{Q} 4$ respectively. 
11) Total exports decrease by $0.0001 \%$ to $0.0025 \%$ in $2016 \mathrm{Q} 1$ and $2017 \mathrm{Q} 4 \mathrm{re}-$ spectively. Oil exports did not respond to a positive foreign country productivity shock and remained unchanged over the period of simulations, while service exports also decreased by $0.002 \%$ to $0.07 \%$ in 2016Q1 and 2017Q4 respectively. However, non-oil exports decrease by $0.001 \%$ to $0.044 \%$ in $2016 \mathrm{Q} 1$ and 2017Q4 respectively.

\section{Findings and Discussions}

A positive foreign country productivity shock increases the current account balance, capital financial flows, foreign debt flows, foreign portfolio investments, nominal exchange rate, real exchange rate, reserves, and remittances. On the other hand, a positive shock to foreign country productivity will also bring about decreases in foreign direct investments, imports, total exports, non-oil exports, and service exports. A negative foreign country productivity shock increases the current account balance, capital financial flows, foreign debt flows, foreign portfolio investments, nominal exchange rate, real exchange rate, reserves, and remittances. On the other hand, a positive shock to foreign country productivity will also bring about decreases in foreign direct investments, imports, total exports, non-oil exports, and service exports. The responses elicited for foreign productivity shocks confirm the findings of [17], that there exist significant interactions between a countries economic growth and international policies.

The simulation results show that, an increase in demand-captured by positive shocks to foreign country output-actually reduces Nigeria's non-oil exports. However, it will be difficult to attribute such findings to domestic protectionist policies of Nigeria's trade partners as claimed by [29] and [19] for trade between developing and developed economies. The expectation was that with this shock, there would be an increase in the demand for Nigeria's non-oil exports. This may indicate either the low quality of Nigeria's non-oil export or the low demand for such non-oil exports. Another reason for Nigeria's non-oil exports not benefiting from an increase in demand from foreign trade partners is based on the claim by [18] and [30] that trade with developing countries can be beneficial as it will bring about specialization in advanced sectors, with the caveat that specific conditions-the existence of learning by doing and homothetic preferences-which are lacking in developing economies must exist.

The study found a striking similarity among the responses of the external sector component responses to positive and negative foreign country productivity shocks. Despite the similarity in responses, the study found that the elicited responses to a foreign country productivity shock outweighs those of a negative foreign country productivity shock. This finding shows that, it does not matter if shocks to Nigeria's trading partners are positive or negative, as the components of Nigeria's external sector will respond in like manner to these shocks. This can be explained by existing unfavourable terms of trade as well as the relatively smaller proportion of Nigeria's trade compared to that of the United States of 
America.

\section{Conclusions}

In eliciting responses of Nigeria's external sector components to both positive and negative US productivity shocks, the paper employed a Structural Macroeconomic Model (SMM) which consisted of ten behavioural equations-which described the relationship between endogenous variables and exogenous variables in the SMM-and four identities which we expect will hold true in reality. Using the Gauss-Seidel technique, we simulated an eight period ahead forecast response of all the endogenous variables in the SMM and compared the responses to a baseline response. The baseline response was simulated under the assumption that all the variables will continue on their trend path without any significant change.

The simulated responses for this study find an overwhelming evidence that US productivity shocks have significant effects on Nigeria's nominal and real exchange rates, remittances, and capital financial flows. However, we found that both positive and negative shocks to US productivity had very limited effects on the components of Nigeria's exports: total export, oil export non-oil exports, and service exports. Also, we found weak responses to US productivity shocks on reserves and foreign direct investments. The simulation results show symmetry between positive and negative productivity shocks.

\section{Conflicts of Interest}

The authors declare no conflicts of interest regarding the publication of this paper.

\section{References}

[1] Imoisi, A.I. (2012) Trends in Nigeria's Balance of Payments: An Empirical Analysis from 1970-2010. European Journal of Business and Management, 4, 210-217.

[2] Yllmaz, Ö. and Akinci, M. (2011) Current Account and Economic Growth Relationship between Balance Sheet: The Case of Turkey. Ataturk University Social Journal of the Institute of Science, 15, 363-377.

[3] Telatar, O.M. and Terzi, A. (2009) Turkey in the Economic Growth and Current Account Balance Relationship. Ataturk University Faculty of Economics and Administrative Sciences School Journal, 23, 119-134.

[4] Garnaut, R., Song, L. and Woo, W.T. (2009) China's New Place in a World in Crisis: Economic Geopolitical and Environmental Dimensions. Australian National University E-Press. https://doi.org/10.22459/CNPWC.07.2009

[5] Henriksen, E.R. (2005) A Demographic Explanation of U.S. and Japanese Current Account Behaviour.

[6] Fausten, D.K. (2009) Macroeconomic Policy and the External Sector. In: International Economics, Finance and Trade, Vol. 1, Encyclopedia of Life Support Systems (EOLSS), 195.

[7] IMF (2003) Fund Assistance for Countries Facing Exogenous Shocks. SM/03/288. 
https://doi.org/10.5089/9781498329170.007

[8] Central Bank of Nigeria (2013) Modelling the External Sector of the Nigerian Economy. Research Department, Abuja.

[9] Bhanumurthy, N.R., Bose, S. and Swayamsiddha, P. (2014) Modelling India's External Sector: Review and Some Empirics. National Institute of Public Finance and Policy, Working Paper, No. 2014-138.

[10] Bsharat, M. (2014) The Effect of Exogenous Factors on the Performance of External Sector in Palestine: A VECM Approach. Palestine Monetary Authority Working Paper.

[11] NERI (2014) Lao PDR's Macroeconomic Model. The Technical Background Paper, $2^{\text {nd }}$ Edition.

[12] Gurara, D.Z. (2013) A Macroeconometric Model for Rwanda. ADB Working Paper Series, No. 177.

[13] Akanbi, O.A. and Du Toit, C.B. (2010) Macroeconometric Modelling for the Nigerian Economy: A Growth Poverty Gap Analysis. Economic Modelling, 28, 335-350. https://doi.org/10.1088/1475-7516/2010/08/015

[14] Karnik, A. and Fernandes, C. (2005) Macroeconometric Modelling for an Oil Development Economy: An Instruments Targets Approach for the UAE Economy. Economic Research Forum Annual Conference, Cairo, March 2005.

[15] Livermore, S. (2005) An Econometric Model of the Slovak Republic. World Bank Public Finance Management Reform Project.

[16] Lord, M.J. and ADB (2002) Modelling the Macroeconomy of Bangladesh. MPRAPaper, No. 41171.

[17] Baldwin, R.E. (2003) Openness and Growth: What's the Empirical Relationship? NBER Working Paper No. 9578. https://doi.org/10.3386/w9578

[18] Rodriguez, F. and Rodrik, D. (1999) Trade Policy and Economic Growth: A Skeptic's Guide to the Cross-National Evidence. NBER Working Paper 7081. https://doi.org/10.3386/w7081

[19] Dollar, D. and Kraay, A. (2001) Growth Is Good for the Poor. Policy Research Working Paper. http://elibrary.worldbank.org/doi/abs/10.1596/1813-9450-2587

[20] Arora, V. and Vamvakidis, A. (2004) How Much Do Trading Partners Matter for Economic Growth? IMF Working Paper, WP/04/26.

https://doi.org/10.5089/9781451844412.001

[21] Adeleye, J.O., Adeteye, O.S. and Adewuyi, M.O. (2015) Impact of International Trade on Economic Growth in Nigeria. International Journal of Financial Research, 6, 163-172. https://doi.org/10.5430/ijfr.v6n3p163

[22] Arodoye, N.L. and Iyoha, M.A. (2014) Foreign Trade-Economic Growth Nexus: Evidence from Nigeria. CBN Journal of Applied Statistics, 5, 121-141.

[23] Spilimbergo, A. (2000) Growth and Trade: The North Can Lose. Journal of Economic Growth, 5, 131-146. https://doi.org/10.1023/A:1009882419420

[24] Cohen, D. (2004) Constructing a Structural Macroeconomic Model Using Multiple Techniques. Senior Scholar Papers. Paper 286.

[25] Tinbergen, J. (1939) Statistical Testing of Business Cycle Theories. League of Nations, Geneva.

[26] Fair, R.C. (2013) Macroeconomic Modelling. https://fairmodel.econ.yale.edu/mmm2/mm.pdf

[27] Fair, R.C. (1984) Specification, Estimation, and Analysis of Macro Econometric 
Models. Harvard University Press, Cambridge.

[28] Fair, R.C. (2004) Estimating How the Macro Economy Works. Harvard University Press, Cambridge.

[29] Frankel, J.A. and Romer, D. (1999) Does Trade Cause Growth? American Economic Review, 89, 379-399. https://doi.org/10.1257/aer.89.3.379

[30] Sachs, J.D. and Warner, A. (1995) Economic Reform and the Process of Global Integration. Brooking Papers of Economic Activity, 1995, 1-118.

https://doi.org/10.2307/2534573 